\title{
International Trials of Vertical Flow Reactors for Coal Mine Water Treatment
}

\author{
Ivan Blanco $^{1}$ - Devin J. Sapsford ${ }^{1} \cdot$ Dave Trumm $^{2} \cdot$ James Pope $^{2} \cdot$ Natalie Kruse $^{3}$ • \\ Young-wook Cheong ${ }^{4} \cdot$ Hamish McLauchlan ${ }^{5} \cdot$ Eden Sinclair $^{5} \cdot$ Paul Weber $^{6}$. \\ William Olds ${ }^{6}$
}

Received: 26 May 2016 / Accepted: 13 October 2017 / Published online: 26 October 2017

(c) The Author(s) 2017. This article is an open access publication

\begin{abstract}
Vertical flow reactors (VFRs) were tested at coal mine sites in New Zealand, South Korea, and the USA. The objective was to evaluate the iron removal efficiency and iron removal mechanisms during field trials at low $\mathrm{pH}$ and circumneutral $\mathrm{pH}$, and to evaluate the potential use of VFRs as stand-alone systems or in combination with other passive treatment technologies. Total iron and manganese removal efficiencies at circumneutral $\mathrm{pH}$ (6-8) often exceeded 90\%, with effluent concentrations less than $1 \mathrm{mg} / \mathrm{L}$. This is attributed to both homogeneous and heterogenous Fe(II) oxidation and filtration of the precipitated ferrihydrite. Iron removal efficiencies at moderately acidic conditions ( $\mathrm{pH} 3-4.5)$ averaged close to $40 \%$, with an average $71.0 \%$ removal in one of the trials after iron removal capacity was stabilized. Microbial $\mathrm{Fe}$ (II) oxidation and precipitation as schwertmannite together with aggregation of colloidal and nano-particulate $\mathrm{Fe}$ (III) are suspected to be the main removal mechanisms. Iron solubility limited removal under very acidic conditions $(\mathrm{pH}<3)$. The reproducibility of the results with respect to
\end{abstract}

Devin J. Sapsford

SapsfordDJ@cardiff.ac.uk

1 Cardiff School of Engineering, Cardiff University, Queen's Building, The Parade, Cardiff CF24 3AA, UK

2 CRL Energy Ltd, Christchurch Office, 97 Nazareth Ave., Christchurch 8540, New Zealand

3 Voinovich School of Leadership and Public Affairs, Ohio University, Building 22, The Ridges, Athens, $\mathrm{OH} 45701$, USA

4 Geologic Environmental Division, the Korea Institute of Geoscience and Mineral Resources (KIGAM), 30 Gajeong-dong, Yuseong-gu, Daejeon 305-350, South Korea

5 Bathurst Resources Ltd., Wellington, New Zealand

6 O'Kane Consultants Ltd., Darfield, New Zealand previous research confirmed that VFRs can be used as standalone passive treatment systems for iron removal from mine waters with a footprint less than half of the area required by a conventional aerobic wetland. A VFR can also provide useful iron pretreatment for other passive treatment systems under circumneutral conditions, but would have to be combined with alkaline generating systems to achieve full iron removal from acidic mine waters.

Keywords Iron $\cdot$ Manganese $\cdot$ Mine water $\cdot$ Passive treatment

\section{Introduction}

Ferruginous mine water (MW) discharges generated during operation and after closure of coal mines are a global environmental problem. Although active MW treatment schemes may be a viable option during mining, passive treatment technologies are preferred at abandoned coal mine sites due to lower construction, operation, and maintenance costs. A variety of passive treatment technologies have been developed over the last three decades, including aerobic and anaerobic wetlands, settling ponds, anoxic limestone drains, successive alkalinity producing systems, diversion wells, bioreactors, and limestone or slag leaching beds (Skousen et al. 2000; Wieder and Lang 1982). The choice of an appropriate passive treatment system is site specific and primarily depends on the MW chemistry (dissolved oxygen content, $\mathrm{Fe}^{2+} / \mathrm{Fe}^{3+}$ ratio, $\mathrm{Al}$ concentration, $\mathrm{pH}$ ) and flow rate, though other characteristics, such as topography and available land area, may also be limiting in certain areas (Trumm 2010). Process selection is often made with reference to flow charts that simplify the selection of passive treatment technologies 
based on MW chemistry. These flow charts have evolved as research in MW treatment has progressed (Hedin et al. 1994; Rose 2010; Skousen and Ziemkiewicz 2005).

The technology referred to here as a vertical flow reactor (VFR) was originally developed after ochre accretion was observed on the surface of a vertical compost bed on the Gwenffrwd anaerobic wetland (Wales, UK). From this observation, an alternative to more conventional passive treatment systems was conceived; its novelty is related to the vertical flow and removal of iron within an accreting ochre bed, rather than in any substrate or media (Dey et al. 2003). The VFR is similar in concept to slow sand filters or vertical constructed wetlands, and operates by passing MW downward through a gravel bed, which supports the accreting bed of ochre. The configuration of a VFR can include two compartments that may be configured with different flow ratios (Yim et al. 2014), allowing treatment to occur in an 'active' compartment, whilst the second, which is available to be de-sludged and recommissioned, can receive storm flow and acts as an overflow to ensure treatment in case the active compartment fails (Sapsford and Williams 2009). Iron removal is intensified and ochre can be recovered as a sludge relatively free of plant detritus, which is amenable for recovery of ochre as a resource where/when such opportunities arise (e.g. Sapsford et al. 2015).

Previous research on VFR technology has documented iron removal from coal MW, with different iron removal mechanisms associated with different conditions. In circumneutral net-alkaline water, iron removal occurred by self-filtration through the ochre bed and heterogeneous iron oxidation and precipitation of hydrated ferric oxides and oxyhydroxides within the ochre bed (Sapsford and Williams 2009; Sapsford et al. 2007). Under acidic conditions, iron removal occurred predominantly by heterogeneous precipitation and/or aggregation of nano-particulate $\mathrm{Fe}(\mathrm{III})$ precipitates (Florence et al. 2016). Although these researchers have shown that VFRs are a good alternative to other passive treatment systems, the technology still required additional field trials to better define its range of applicability and reproducibility of results under different water chemistries to generate more confidence in the technology as a reliable option.

This work presents new data relevant to VFRs from field trials at coal mine sites with varying water chemistries in New Zealand, South Korea, and Ohio (USA). Iron removal mechanisms and efficiencies were evaluated in the context of previous research, as well as the suitability of VFR systems to be used as an alternative to, or in combination with, other passive treatment technologies.

\section{Materials and Methods}

\section{Summary of Previous United Kingdom VFR Trials}

The original VFR pilot-scale system (referred to as UK1) was installed at the former Taff Merthyr colliery near Merthyr Tydfil (South Wales), where net-alkaline MW was collected, pumped, and treated in a system of conventional settlement lagoons and aerobic wetlands. That VFR consisted of a $21.6 \mathrm{~m}^{2}$ bed of $20 \mathrm{~mm}$ angular sandstone gravel $100 \mathrm{~mm}$ thick, overlain by $6 \mathrm{~mm}$ angular sandstone gravel $100 \mathrm{~mm}$ thick. The bed sat on a plenum floor comprising galvanized steel mesh sheets supported by $300 \mathrm{~mm}$ high concrete pillars. The MW passed through the bed into the underdrain, under a baffle wall, and up through a rise chamber where it exited the system. A detailed description of the system, schematics, photographs, and water and sludge sampling and analysis are available in previous publications (Sapsford et al. 2007; Barnes 2008; Sapsford and Williams 2009).

VFR trial UK2 was located at the Cwm Rheidol complex (Ceredigion, Wales), a former $\mathrm{Pb} / \mathrm{Zn}$ mine that discharges net-acidic MW (Table 1). The VFR was constructed in an intermediate bulk container (IBC) of $1 \mathrm{~m}^{3}$. Inside the IBC, a drainage pipe was covered by a layer of $30 \mathrm{~mm}$ angular coarse gravel which acted as support for another $200 \mathrm{~mm}$ layer of 5-10 mm siliceous gravel. Mine water flowed down through the IBC and was collected by a drainage pipe, which directed it up through a swan neck outlet. The driving head within the IBC was adjusted to a final target of $0.61 \mathrm{~m}$. An ochre sludge layer was allowed to accumulate atop the gravel layer, decreasing the bed permeability as it built up (Fig. 1). A description of the water and sludge sampling and analysis is available (Florence et al. 2016).

\section{New Zealand VFR Trials}

VFR trial NZ1 was located at an active New Zealand underground coal mine. The netalkaline circumneutral MW drains from the walls of an old open pit. VFR trials NZ2 and VFR NZ3 were located in New Zealand opencast coal mines and received net-acidic MW that originates from overburden waste rock dumps and an underground mine adit, respectively. VFR trials NZ4 and NZ5 were located at the abandoned, underground Bellvue coal mine, on the west coast of the South Island of New Zealand, approximately $15 \mathrm{~km}$ northeast of Greymouth. The mine entry is on a hillside approximately $30 \mathrm{~m}$ above a nearby creek. A pool of AMD water at the entry drains to a cascade and flows down the slope to the nearby Cannel Creek. VFR NZ4 received oxidized MW from the base of the cascade, whereas NZ5 received non-aerated water directly from the mine entry.

All of these VFR trials followed the design used by Florence et al. (2016), which in turn was based on the work 


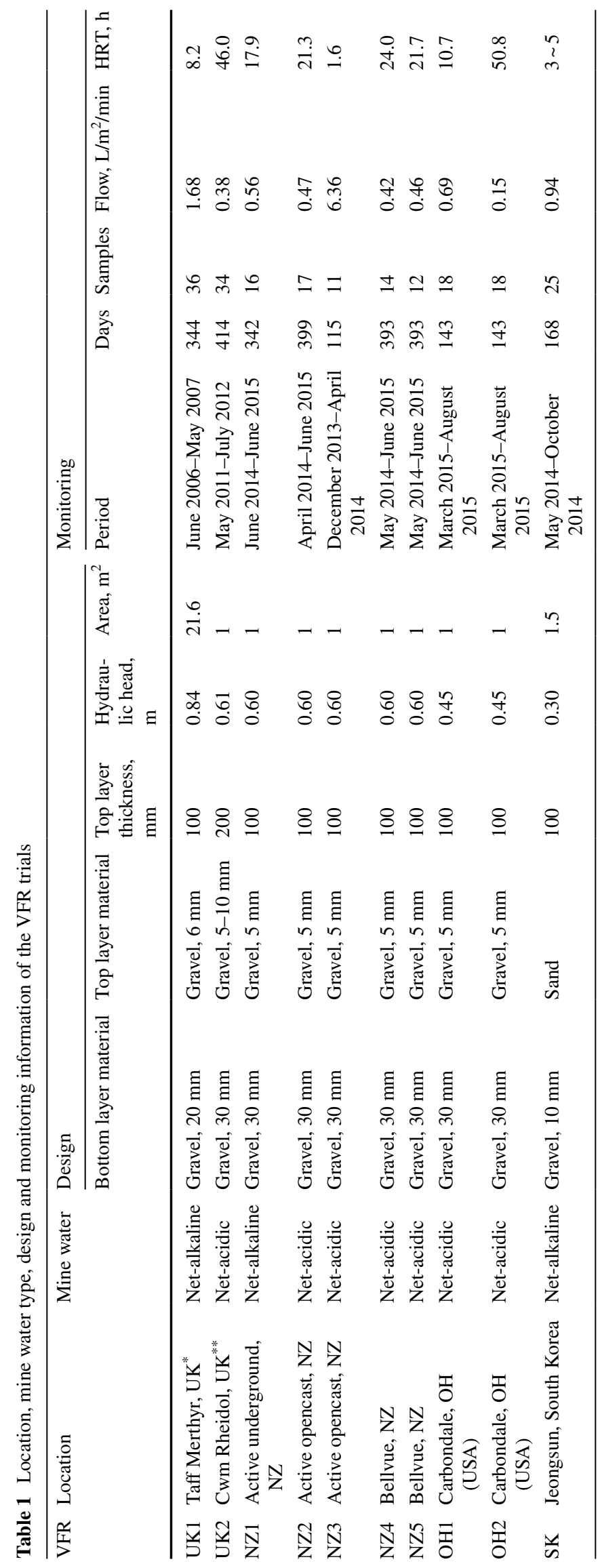


Fig. 1 Conceptual diagram of VFR field trial UK2. Adapted from Florence et al. (2016)

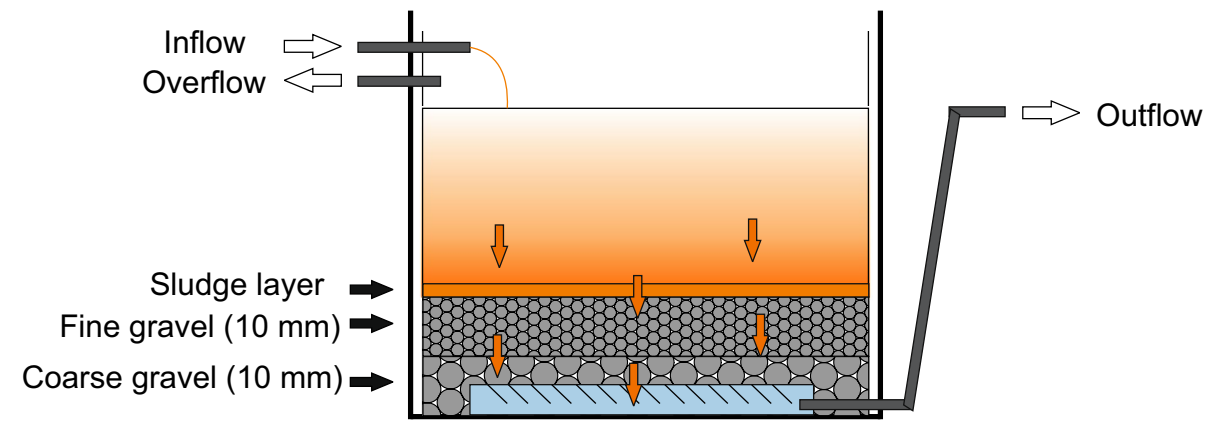

of Dey et al. (2003). Each trial consisted of a $1 \mathrm{~m}^{3}$ IBC adapted as a VFR treatment tank with a drain pipe covered by a $30 \mathrm{~mm}$ coarse gravel layer that acts as support for a layer of $5 \mathrm{~mm}$ gravel $100 \mathrm{~mm}$ thick. The swan neck outlet was configured so that the targeted hydraulic head difference between the inlet and outlet was $0.6 \mathrm{~m}$.

The NZ1, NZ2, NZ4, and NZ5 trials were monitored fortnightly through 2014 and monthly in 2015. A summary of the monitoring period and number of sampling events is provided in Table 1. Influent flow was monitored by timing the length of time to fill a measuring cylinder to a known volume. The target inflow was set between 450 and $550 \mathrm{~mL} /$ $\mathrm{min}$. This target flow rate was used only for trials NZ1, NZ2, NZ4, and NZ5. The flow rates in the other VFR trials is shown in Table 1. Inlet and outlet $\mathrm{pH}$, electrical conductivity (EC), and dissolved oxygen (DO) were measured using a portable YSI 556 multi-probe system calibrated in the field.

Inlet and outlet samples were immediately measured in the field for total Fe using Hach Method 8008 and a Hach DR/2400 portable spectrophotometer. Samples were then filtered using a disposable syringe and $0.45 \mu \mathrm{m}$ filters and measured for dissolved $\mathrm{Fe}$ following the same procedure. $\mathrm{Fe}$ (II) was also measured in samples using the Hach Method 8146 (1,10 Phenanthroline Method) and a Hach DR/2400 portable spectrophotometer. Samples were collected monthly and stored at $4{ }^{\circ} \mathrm{C}$ until sulphate, total acidity (to $\mathrm{pH}$ 8.3) and total alkalinity analyses in the laboratory. Filtered and unfiltered samples were acidified with $0.1 \mathrm{~mL}$ of $20 \% \mathrm{HNO}_{3}$ and stored at $4{ }^{\circ} \mathrm{C}$ until extensively analysed (31 elements) by ICP-MS.

VFR trial NZ3 was operated for a 4 month period (Table 1). Inlet and outlet flows were monitored weekly for $\mathrm{pH}, \mathrm{EC}, \mathrm{DO}$, and oxidation-reduction potential (ORP) using handheld meters. Flow rates were also measured weekly at the outlet of the VFR using a bucket and stopwatch. Samples were collected monthly and analysed for total acidity to $\mathrm{pH}$ 6.5. Inlet and outlet were also added to $\mathrm{HNO}_{3}$ acid-preserved sample bottles and stored at $4{ }^{\circ} \mathrm{C}$ until ICP-MS analysis of $\mathrm{Al}, \mathrm{Fe}, \mathrm{Ni}$, and $\mathrm{Zn}$ following APHA method 3125. Sulphate was analysed by ion chromatography using APHA method 4110 (Rice et al. 2012).
Two sets of experiments were conducted to assess the effect of mixing MW with non-impacted stream water (Cannel Creek) at three ratios $(2: 1,1: 1$, and 1:4) to understand how this might affect $\mathrm{pH}$ and removal of dissolved $\mathrm{Fe}$. The first set of experiments was performed using NZ4 MW and freshwater collected from Cannel Creek (FW) mixed and stirred in an open reactor (bucket) for 2-5 min in the field.

Samples of NZ4 MW and FW were then collected for a second set of experiments to evaluate the effect that a limestone leaching bed would have. These water samples were transported to the laboratory and stored at room temperature. To simulate $\mathrm{CaCO}_{3}$ dissolution in limestone leaching beds, the FW was soaked in 5-10 cm limestone clasts in open reactors for a retention time of $8 \mathrm{~h}$. The treated FW was then mixed with the MW at the same three ratios and stirred in an open reactor for $2-5 \mathrm{~min}$. Filtered samples $(0.45 \mu \mathrm{m})$ were collected from each experiment and acidified with $0.1 \mathrm{~mL}$ of $20 \% \mathrm{HNO}_{3}$ and stored at $4{ }^{\circ} \mathrm{C}$ until ICP-MS analysis for Fe.

\section{Ohio VFR Trials}

VFR trials $\mathrm{OH} 1$ and $\mathrm{OH} 2$ were located in Carbondale, Athens County (Ohio, USA). The net-acidic MW at Carbondale originates from abandoned underground coal mines and is treated next to the seepage point by a calcium oxide dosing unit before it reaches Hewett Fork, tributary of Raccoon Creek (Ohio University 2015). The VFR trials followed the design used by Florence et al. (2016) and receive water directly from the seep. The trials consisted of a $1 \mathrm{~m}^{3} \mathrm{IBC}$ adapted as a VFR treatment tank with a drain pipe covered by a $30 \mathrm{~mm}$ coarse gravel layer $300 \mathrm{~mm}$ thick that acted as support for a layer of $5 \mathrm{~mm}$ gravel $100 \mathrm{~mm}$ thick. The swan neck outlet was configured to have a hydraulic head difference between inlet and outlet of $0.45 \mathrm{~m}$.

The results presented here belong to an intensive sampling of VFR trials performed on the last 3 days of operation before decommission, during which the VFRs were monitored six times every $1.5 \mathrm{~h}$. The $\mathrm{pH}, \mathrm{EC}, \mathrm{DO}$, and ORP were measured using a Myron L Ultrameter II handheld meter and a YSI 556 multi-probe system calibrated in the field. Inlet and outlet flow rates were measured using a bucket 
and stopwatch. Samples were immediately measured in the field for sulphate and total Fe using Hach Method 8008 and 8051 respectively, and a Hach DR/820 portable colorimeter. Samples were then filtered using a disposable syringe and $0.45 \mu \mathrm{m}$ filters and measured for dissolved Fe following the same procedure. Fe(II) was measured using Hach Method 8146 (1,10 phenanthroline method). Twice per day, filtered and unfiltered samples were acidified with $0.1 \mathrm{~mL}$ of $20 \%$ $\mathrm{HNO}_{3}$ and stored at $4{ }^{\circ} \mathrm{C}$ until ICP-OES analysis of major cations (Al, $\mathrm{Fe}, \mathrm{Mg}, \mathrm{Mn}, \mathrm{Na}, \mathrm{K}$ ) in the laboratory. Acidity values were calculated following Kirby and Cravotta III (2005):

$$
\begin{aligned}
\text { Acidity }_{a s} \frac{m g}{L} \mathrm{CaCO}_{3}= & 50\left[\left(\frac{2 F e^{2+}}{56}\right)+\left(\frac{3 F e^{3+}}{56}\right)+\left(\frac{2 M n}{55}\right)\right. \\
& \left.+\left(\frac{3 A l^{3+}}{27}\right)+\left(1000 e^{-p H}\right)\right]
\end{aligned}
$$

An experiment was carried out to evaluate Fe removal in the water column. Untreated MW was collected from the seep and kept undisturbed in three open reactors in the field. The static reactors were sampled at 0,24 , and $48 \mathrm{~h}$. The $\mathrm{pH}$, $\mathrm{EC}$, DO, ORP, total Fe, dissolved $\mathrm{Fe}$, and $\mathrm{Fe}(\mathrm{II})$ were measured in the field following the same methodology described for the $\mathrm{OH} 1$ and $\mathrm{OH} 2$ trials.

\section{South Korea VFR Trials}

VFR trial SK was located in Jeongsun, Kangwon province, South Korea. The SK trial followed the design used by Sapsford et al. (2007) and received water collected directly from the shaft of an abandoned underground coal mine. The trial consisted of a $1.5 \mathrm{~m}^{2}$ footprint container as a VFR treatment tank with a bed of $10 \mathrm{~mm}$ coarse gravel $100 \mathrm{~mm}$ thick, overlain by a sand layer $100 \mathrm{~mm}$ thick. The bed sat on a perforated steel plate to allow an underdrain chamber, as described for VFR UK1.

The VFR trial was monitored weekly (Table 1). Inlet and outlet flow rates were measured using a bucket and stopwatch. The $\mathrm{pH}, \mathrm{EC}, \mathrm{DO}$, and ORP were measured at the inlet and outlet using a portable water parameter probe (HACH HQ40d). Bulk and filtered samples were collected using a disposable syringe and $<0.45 \mu \mathrm{m}$ filters and were acidified with concentrated $\mathrm{HCl}$ for $\mathrm{Fe}$ (II) or concentrated $\mathrm{HNO}_{3}$ for $\mathrm{Fe}$ and $\mathrm{Mn}$, and stored at $4{ }^{\circ} \mathrm{C}$ until ICP analysis (Ultima 2C, Horiba-Yuvon, France).

\section{Sludge Sampling and Analysis}

At the end of the operational period, VFR trials NZ1, NZ2, $\mathrm{NZ3}, \mathrm{NZ4}, \mathrm{NZ} 5, \mathrm{OH} 1$, and $\mathrm{OH} 2$ were drained to evaluate the development of any sludge layer. Although VFR trial NZ3 was decommissioned after 4 months of monitoring, drainage for evaluation of the sludge layer occurred 13 months later. Before sludge sampling, the thickness of the sludge layer was measured as the average of five measurements from the top of the gravel layer to the top of the sludge layer.

After drainage, sludge samples were collected from the VFR trials, sealed in polyethylene zipper storage bags, transported to the laboratory to be oven dried at $60{ }^{\circ} \mathrm{C}$ and left to cool to room temperature in silica gel desiccators. The dried ochre samples were microwave acid-digested using an Anton Paar Multiwave 3000 microwave digester system: $0.1 \mathrm{~g}$ of sample was dissolved in $6 \mathrm{~mL}$ of a 1:1 mixture of $\mathrm{HCl}$ and $\mathrm{HNO}_{3}$ and digested in the microwave with a temperature ramp of $10^{\circ} \mathrm{C} \cdot \mathrm{min}^{-1}$ up to $200^{\circ} \mathrm{C}$ and held at that temperature for $30 \mathrm{~min}$. The vessel contents was transferred into a volumetric flask and diluted with deionized water up to $50 \mathrm{~mL}$. An aliquot of the final solution was finally submitted for analysis on an ICP-OES Perkin Elmer Optima 2100D. Dried ochre samples were also analysed for sulphur in a SC144DR Leco Furnace. XRD analyses were performed using a Phillips PW3830 X-ray generator of $\mathrm{Cu} k \alpha$ radiation equipped with a Phillips Pw1710 controller.

\section{Geochemical Modeling}

Geochemical modeling was used to evaluate the speciation of the New Zealand and Ohio MW and calculate the saturation indexes (SI) of target minerals using the geochemical software PHREEQC v.3 (Parkhurst and Appelo 2013). The wateq4f database was modified to account for the schwertmannite solubility products $\left(\log K_{\mathrm{sp}}\right) 7.06$ (Kawano and Tomita 2001) and 18.0 (Bigham et al. 1996) at the temperature at which the tests were conducted. Redox couple $\mathrm{Fe}^{2} / \mathrm{Fe}^{3}$ was used in speciation calculations in the case of missing ORP values.

\section{Results and Discussion}

Different coal MW with a range of $\mathrm{pH}$ values were selected to test the treatment capacity of the VFR technology. A summary of the physico-chemical characteristics and metal concentrations at the inlet and outlet of the VFR trials is shown in Tables 2 and 3, respectively. Since $\mathrm{H}^{+}$concentration plays a key role in Fe oxidation kinetics and HFO solubility, the MWs were grouped according to their $\mathrm{pH}$ into three categories: circumneutral ( $\mathrm{pH} 6-8)$, moderately acidic $(\mathrm{pH} 3-4.5)$, and acidic $(\mathrm{pH}<3)$. 
Table 2 Average physico-chemical parameters at the inlet (I) and outlet (O) of the VFR trials

\begin{tabular}{|c|c|c|c|c|c|c|c|c|c|c|}
\hline VFR & $\begin{array}{l}\mathrm{pH} \\
\mathrm{I}\end{array}$ & $\begin{array}{l}\mathrm{pH} \\
\mathrm{O}\end{array}$ & $\begin{array}{l}\mathrm{T},{ }^{\circ} \mathrm{C} \\
\mathrm{I}\end{array}$ & $\begin{array}{l}\mathrm{T},{ }^{\circ} \mathrm{C} \\
\mathrm{O}\end{array}$ & $\begin{array}{l}\text { Cond, } \mu \mathrm{S} / \mathrm{cm} \\
\text { I }\end{array}$ & $\begin{array}{l}\text { Cond, } \mu \mathrm{S} / \mathrm{cm} \\
\mathrm{O}\end{array}$ & $\begin{array}{l}\text { D.O., mg/L } \\
\text { I }\end{array}$ & $\begin{array}{l}\text { D.O., mg/L } \\
\text { O }\end{array}$ & $\begin{array}{l}\text { ORP, } \mathrm{mV} \\
\mathrm{I}\end{array}$ & $\begin{array}{l}\text { ORP, mV } \\
\text { O }\end{array}$ \\
\hline \multicolumn{11}{|c|}{ Circum-neutral mine waters (pH 6-8) } \\
\hline UK1 & 6.7 & 6.8 & 11.6 & 11.6 & na & na & 3.7 & 5.2 & 219 & 297 \\
\hline NZ1 & 7.4 & 7.4 & 8.9 & 10.0 & 140 & 141 & 10.9 & 10.0 & na & na \\
\hline SK & 6.6 & 6.8 & 16.0 & 16.8 & 423 & 409 & 9.1 & 8.8 & 63.8 & 102 \\
\hline \multicolumn{11}{|c|}{ Moderately acidic mine waters ( $\mathrm{pH} 3-4$ ) } \\
\hline UK2 & 3.0 & 2.9 & 13.1 & 13.7 & na & na & 7.8 & 6.2 & 646 & 693 \\
\hline NZ2 & 3.2 & 3.1 & 14.5 & 10.5 & 2078 & 1959 & 7.6 & 8.2 & na & na \\
\hline $\mathrm{OH} 1$ & 4.2 & 4.3 & 20.6 & 23.2 & 1583 & 1534 & 2.5 & 3.6 & 214 & 267 \\
\hline $\mathrm{OH} 2$ & 4.2 & 4.7 & 21.0 & 24.2 & 1578 & 1628 & 2.1 & 2.2 & 208 & 174 \\
\hline \multicolumn{11}{|c|}{ Acidic mine waters $(\mathrm{pH}<3)$} \\
\hline NZ3 & 2.8 & 2.8 & 11.9 & 14.5 & 688 & 732 & 3.0 & 3.0 & 431 & 457 \\
\hline NZ4 & 2.6 & 2.6 & 12.9 & 11.4 & 1296 & 1390 & 10.1 & 9.9 & na & na \\
\hline NZ5 & 2.6 & 2.6 & 13.3 & 10.3 & 1522 & 1433 & 1.5 & 4.4 & na & na \\
\hline
\end{tabular}

\section{Circumneutral Mine Waters (pH 6-8)}

Despite differences in geographic location, the net-alkaline circumneutral MW treated (UK1, NZ1, SK) in the VFR trials had less mineralization than the other MW, as indicated by the low EC values (Table 2), sulphate, and metal concentrations (Table 3). Fe was the main element of concern, with total inlet concentrations ranging between 1.14 and $21.3 \mathrm{mg} / \mathrm{L}$ (Fig. 2a). However, their inlet Fe composition varied significantly, with inlet average Fe particulate contents between 11 and 55\%, average inlet $\mathrm{Fe}$ (II) concentrations between 35 and $84 \%$, and average dissolved $\mathrm{Fe}(\mathrm{III})$ concentrations between 5 and 33\% (Table 3; Fig. 2b).

Fe treatment was excellent in these UK1 and NZ1 trials; average removal efficiencies often exceeded $90 \%$ (Fig. 2c) and Fe discharges were generally less than $1 \mathrm{mg} / \mathrm{L}$ (Table 3 ). Previous research conducted at trial UK1 showed that Fe removal at circumneutral $\mathrm{pH}$ was achieved through a combination of mechanisms including (1) self-filtration of particulate $\mathrm{Fe}$ as it passes through the ochre and gravel beds, (2) oxidation of $\mathrm{Fe}(\mathrm{II})$ in the water column and subsequent precipitation and filtration of HFO on the bed, and (3) heterogeneous catalytic oxidation of $\mathrm{Fe}(\mathrm{II})$ and subsequent accretion of HFO around pre-existing HFO particles in the accumulating bed (Sapsford and Williams 2009).

Fe removal efficiencies in the SK trial ranged between 0 and $94.5 \%$, with an average of $46.4 \%$ and outlet concentrations generally less than $2 \mathrm{mg} / \mathrm{L}$ (Table 3; Fig. 2c). Despite differences in overall $\mathrm{Fe}$ treatment among the trials, similar dissolved $\mathrm{Fe}$ and $\mathrm{Fe}(\mathrm{II})$ removal efficiencies, $\mathrm{pH}$ values, and DO concentrations among the trials (Table 2) indicate that removal of dissolved $\mathrm{Fe}(\mathrm{II})$ and $\mathrm{Fe}(\mathrm{III})$ at the NZ1 and SK trials followed the predominant mechanisms observed in the UK1 trial: homogeneous/heterogeneous oxidation of Fe(II) and precipitation, filtration, and accretion of HFO particles (Geroni 2011).

The lower Fe treatment efficiencies achieved at trial SK (Fig. 2c) is attributed to deficient self-filtration of particulate iron through the ochre and gravel beds. This was confirmed by the high Fe particulate content at the effluent (Table 3; Fig. 2b). The deficient particulate filtration may be due to the higher flow rate or the existence of preferential pathways, particularly down the walls of the reactor. This problem was noted in the commissioning stage of the UK1 trial and was prevented by placing a fillet of sand at the contact between the gravel bed and reactor wall. Self-filtration by the ochre filter cake was also important at the NZ1 trial, as indicated by the amount of particulate $\mathrm{Fe}$ in the influent when compared to the UK1 trial. The NZ1 MW showed a characteristic orange color, indicating the presence of suspended HFO in the water column. Moreover, geochemical modeling of the inlet NZ1 MW confirmed that it was supersaturated with respect to HFO (Table 4).

Drainage of the NZ1 trial and visual inspection afterwards confirmed the formation of a $2 \mathrm{~cm}$ thick ochre sludge layer after 12 months of continuous operation. XRD and ICP-OES analyses (Table 5) indicated that the sludge layer consisted of an amorphous $\mathrm{Fe}$ precipitate with trace concentrations of $\mathrm{Mn}$ and $\mathrm{Ca}$ as the main second and third element concentrations, in similar proportions to UK1 sludge samples (Sapsford et al. 2007).

The VFR trials removed Mn surprisingly well at circumneutral $\mathrm{pH}$ with average removal efficiencies of $97 \%$ at the NZ1 trial, and average removal efficiencies of $69.5 \%$ at the SK trial, which often achieved $100 \%$ removal, consistent with those obtained in the UK1 trial (Sapsford et al. 2007). Given that abiotic oxidation rates for Mn(II) are low below pH 9, Mn removal mechanisms within NZ1 and SK were 


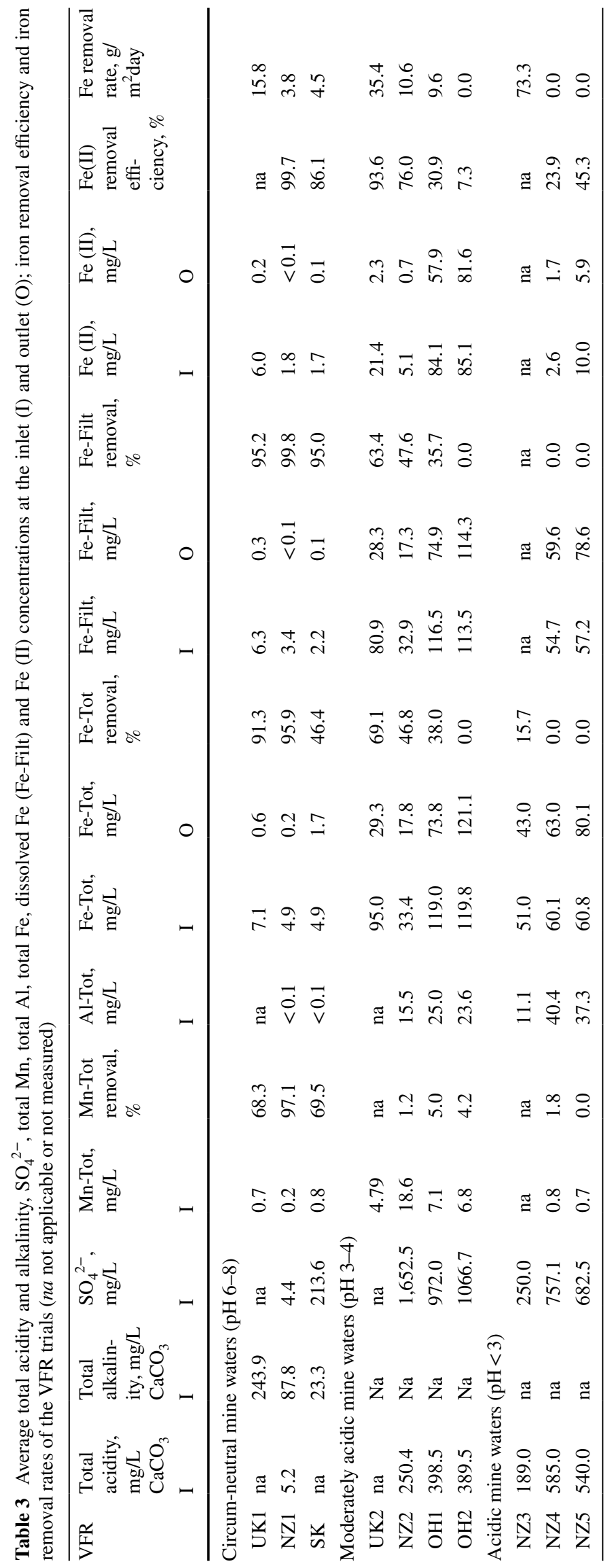



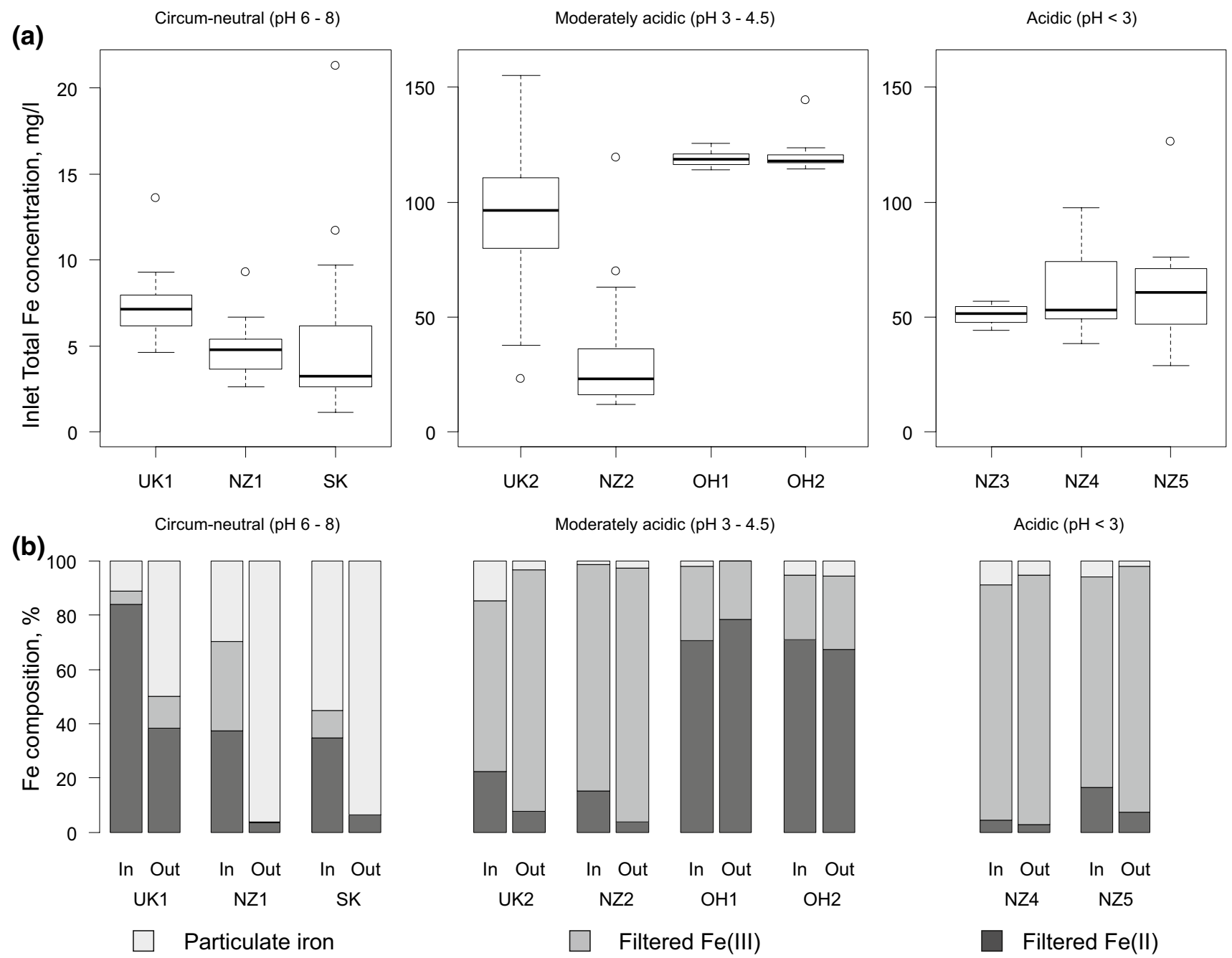

(c)

Circum-neutral ( $\mathrm{pH} 6$ - 8)
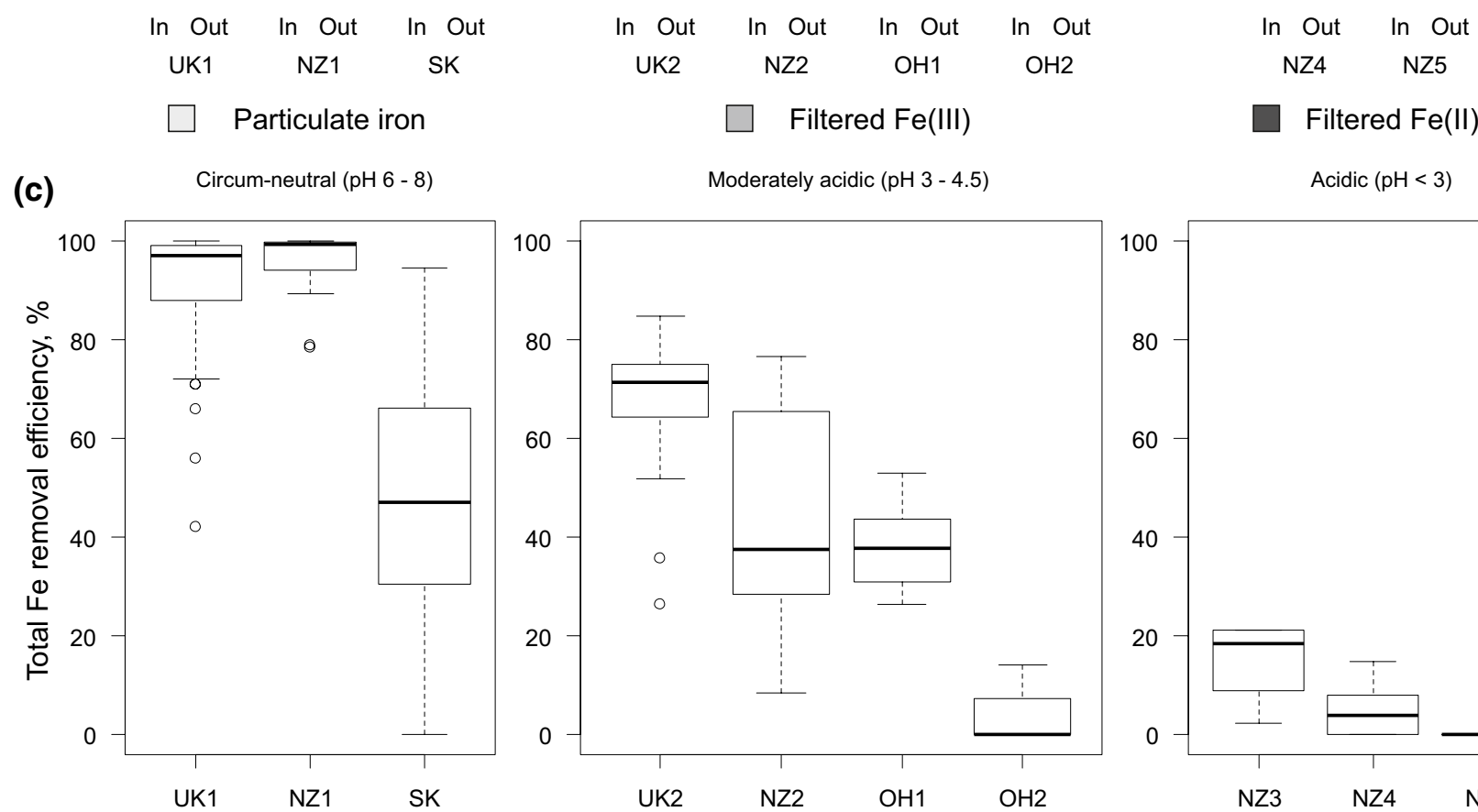

Filtered Fe(II)

Acidic $(\mathrm{pH}<3)$

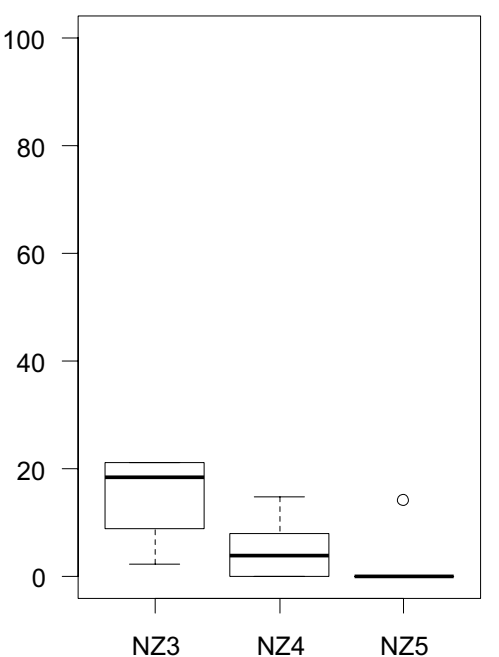

Fig. 2 a Boxplot diagrams of inlet total Fe concentrations for the VFR trials across the $\mathrm{pH}$ range. $\mathbf{b}$ Composition of total iron at the inlet (In) and outlet (Out) of the VFR trials. Total Fe (100\%) is presented as the sum of particulate iron (Total Fe-Filtered Fe, light gray) and filtered iron. Filtered iron is presented as the sum of $\mathrm{Fe}(\mathrm{III})_{(\mathrm{aq})}$ (dark gray) and $\mathrm{Fe}(\mathrm{II})_{(\mathrm{aq})}$ (black). c Boxplot diagrams of total Fe removal efficiency of the VFR trials across the $\mathrm{pH}$ range 
Table 4 Average supersaturation indexes with respect to different minerals in the inlet mine waters calculated with PHREEQC

\begin{tabular}{lrrrrrrrl}
\hline VFR & \multicolumn{1}{c}{$\mathrm{n}$} & \multicolumn{1}{c}{ FER } & GOE & SCH_18 & SCH_7.06 & J-H & J-K & JNa \\
\hline NZ1 & 11 & 4.1 & 9.4 & 23.2 & 34.1 & -8.4 & -0.5 & -4.1 \\
NZ2 & 8 & -0.4 & 5.1 & 3.7 & 14.9 & -0.12 & 3.9 & 0.3 \\
NZ3 & 4 & -5.0 & 0.4 & -32.9 & -21.99 & -14.4 & na & na \\
NZ4 & 6 & -1.5 & 3.9 & -3.5 & 7.5 & -1.6 & 0.9 & -1.9 \\
NZ5 & 6 & -1.7 & 3.8 & -4.8 & 6.1 & -2.2 & 0.3 & -2.5 \\
\hline
\end{tabular}

$N$ number of samples, FER ferrihydrite, GOE Goethite, $S C H \_18$ Schwertmannite calculated using log $\mathrm{K}=18, S C H \_7.06$ Schwertmannite calculated using $\log \mathrm{K}=7.06, \mathrm{~J}-\mathrm{H}$ Jarosite-H, $J-\mathrm{K}$ Jarosite-K, JNa Jarosite-Na
Table 5 Chemical composition of ochre sludge from different VFR trials after ICP-OES analysis (values are in $\mathrm{mg} / \mathrm{kg}$ unless marked otherwise)

\begin{tabular}{llllllllllll}
\hline VFR & $\mathrm{Fe}(\%)$ & $\mathrm{S}(\%)$ & $\mathrm{Ca}$ & $\mathrm{Al}$ & $\mathrm{Mg}$ & $\mathrm{Mn}$ & $\mathrm{Na}$ & $\mathrm{Zn}$ & $\mathrm{K}$ & $\mathrm{Ba}$ & $\mathrm{As}$ \\
\hline $\mathrm{NZ1}$ & 37.4 & 0.07 & $0.89 \%$ & 0.63 & 0.19 & $1.37 \%$ & 0.02 & 0.05 & 0.16 & 0.38 & 0.02 \\
$\mathrm{NZ2}$ & 35.5 & 3.32 & 1.11 & $2.36 \%$ & 3.09 & 0.20 & 0.36 & 0.34 & 12.83 & 0.47 & 0.09 \\
$\mathrm{NZ3}$ & 35.7 & 3.4 & 0.25 & $0.33 \%$ & 0.22 & - & 0.12 & 0.26 & 1.53 & 0.03 & 3.92 \\
$\mathrm{OH} 1$ & 37.6 & 3.9 & 2.59 & $0.35 \%$ & 0.76 & 0.21 & 1.73 & 0.09 & 0.29 & 0.01 & 0.03 \\
$\mathrm{OH} 2$ & 33.8 & 4.0 & 1.20 & $0.92 \%$ & 0.56 & 0.08 & 1.44 & 0.07 & 0.24 & na & 0.01 \\
\hline
\end{tabular}

expected to be similar to those observed in UK1, where Mn removal took place within the bed rather than in the water column, potentially through bacterial oxidation and/or heterogeneous catalysis of $\mathrm{Mn}$ (II) oxidation on $\mathrm{HFO}$ and $\mathrm{Mn}$ oxide surfaces (Geroni 2011).

\section{Moderately Acidic Mine Waters (pH 3-4.5)}

The MWs selected to test the VFR technology under moderately acidic conditions had the highest sulphate and Mn concentrations, moderate $\mathrm{Al}$ concentrations, and a wide range of inlet total Fe concentrations, from UK2 MW with high Fe variability (23.3-155.1 mg/L), those that were generally less than $50 \mathrm{mg} / \mathrm{L}$ (NZ2), and high inlet Fe concentrations at $\mathrm{OH} 1$ and $\mathrm{OH} 2$, with low variability (114.0-144.5 mg/L) (Table 3; Fig. 2a). The inlet particulate iron concentrations were low, indicating that adsorption of dissolved Fe(II) and $\mathrm{Fe}(\mathrm{III})$ to existing precipitates (which is unlikely at low $\mathrm{pH}$ ) and particulate filtration were not important removal mechanisms. Two sets of MWs could be distinguished: MW with low average inlet $\mathrm{Fe}(\mathrm{II})$ content (15-22\%, UK2 and NZ2) and MW with a high average inlet $\mathrm{Fe}(\mathrm{II})$ content $(\approx 70 \%$, $\mathrm{OH} 1$ and $\mathrm{OH} 2$ ) (Table 3; Fig. 2b).

Fe removal efficiencies varied among the VFR trials. VFR trial UK2 was the most successful, removing much (an average of $67.1 \%$ ) of the Fe from the discharge, followed by trial NZ2, which showed a variable Fe removal capacity in the range of $8.3-76.7 \%$, and an average of $45.4 \%$ (Fig. 2c). The Fe removal efficiencies at the $\mathrm{OH} 1$ and $\mathrm{OH} 2$ trials were comparatively low, between 26.3 and $52.9 \%$ (an average of $37.8 \%$ ) at $\mathrm{OH} 1$ and less than $15 \%$ and often close to $0 \%$ at $\mathrm{OH} 2$ (Fig. 2c). However, the $\mathrm{OH} 2$ trial was overflowing at the time of the sampling, indicating that these Fe removal efficiencies were not representative. Moreover, the presence of outlet flow without Fe treatment indicated that untreated MW was bypassing the ochre sludge layer through preferential pathways. It is interesting to show these results as an example of the reduction in treatment performance experienced by a VFR treatment system following a decline in ochre layer permeability.

Biotic Fe(II) oxidation mediated by acidophilic Fe(II) oxidizers is proposed as the main Fe(II) oxidation mechanisms under moderately acidic conditions. Biological oxidation is known to dominate over abiotic Fe(II) oxidation in the 2.5-4.5 pH range (Kirby and Brady 1998) and the presence of bacterial communities dominated by Fe oxidizers is common in this type of MW (e.g. Florence et al. (2016)).

A field experiment in static reactors was performed to simulate Fe oxidation in the water column of the OH1 VFR trial. After a hydraulic residence time (HRT) between 24 and $48 \mathrm{~h}$, decreasing $\mathrm{Fe}(\mathrm{II})$ and filtered Fe concentrations (averaging 29.8 and $38.8 \mathrm{mg} / \mathrm{L} /$ day respectively) were observed in the water column, with a corresponding increase in particulate $\mathrm{Fe}$ (an average of $43.8 \mathrm{mg} / \mathrm{L} /$ day) and DO (averaging $1.5 \mathrm{mg} / \mathrm{L} /$ day). Fe oxidation and precipitation took longer in the water column than in the $\mathrm{OH} 1$ trial (averaging $10.7 \mathrm{~h}$ HRT and $62.3 \mathrm{mg} / \mathrm{L} /$ day removal, respectively), indicating that the ochre sludge layer plays an important role in $\mathrm{Fe}$ oxidation, probably by acting as a supporting substrate for the bacterial community that oxidizes Fe in VFRs under moderately acidic conditions.

Microbial Fe oxidation and precipitation alone could not explain the overall decrease in filtered Fe removed from inlet MW for many of the observed sampling occasions. On 
average, $\mathrm{Fe}(\mathrm{II})$ removal could explain up to 36.1 and $58.9 \%$ of the filtered Fe removed at the outlet of the NZ2 and OH1 VFR trials, respectively. This suggests that another mechanism was important in the removal of filtered $\mathrm{Fe}$ in these VFR trials. Heterogeneous precipitation of Fe(III) and/or aggregation of nano-particulate $\mathrm{Fe}$ (III) precipitates are the likely candidates, as these were identified as the predominant $\mathrm{Fe}$ (III) removal mechanisms in the UK2 trial (Florence et al. 2016).

With the exception of the first two sampling events, $\mathrm{Fe}$ removal in trial NZ2 increased gradually over time until stabilizing at $61.1-76.7 \%$ (averaging $71.0 \%$ ) during the last 5 sampling episodes, similar to what occurred in trial UK2 (Fig. 3). Lower HRTs (Table 1) and inlet Fe concentrations at NZ2 than in the UK2 trial (Table 3) likely slowed development of the ochre sludge layer, delaying the increase of $\mathrm{Fe}$ removal rates to the levels achieved in the UK2 trial. It is proposed that biotic $\mathrm{Fe}(\mathrm{II})$ oxidation and heterogeneous $\mathrm{Fe}(\mathrm{III})$ precipitation (the MW was supersaturated with respect to schwertmannite, Table 4) were the main removal mechanisms during the first sampling episodes. As the ochre layer developed, increased aggregation of colloidal and nano-particulate $\mathrm{Fe}(\mathrm{III})$ precipitates $(<0.45 \mu \mathrm{m})$ on the ochre would have contributed to overall Fe removal.

The NZ2, OH1, and OH2 VFR trials were drained at the end of the operational period. While the ochre layer at trial NZ2 was slimy and $1 \mathrm{~cm}$ thick after 14 months of operation, the ochre developed at the $\mathrm{OH} 1$ and $\mathrm{OH} 2$ trials was porous due to bubbles trapped in its structure, and had accumulated an average thickness of 1 and $2 \mathrm{~cm}$ respectively after only 6 months of operation. Interestingly, this porous structure conferred low density properties to the sludge. Stirring of the VFR trial resulted in intensive bubbling and floating of sludge aggregates on top of the water column. This porous

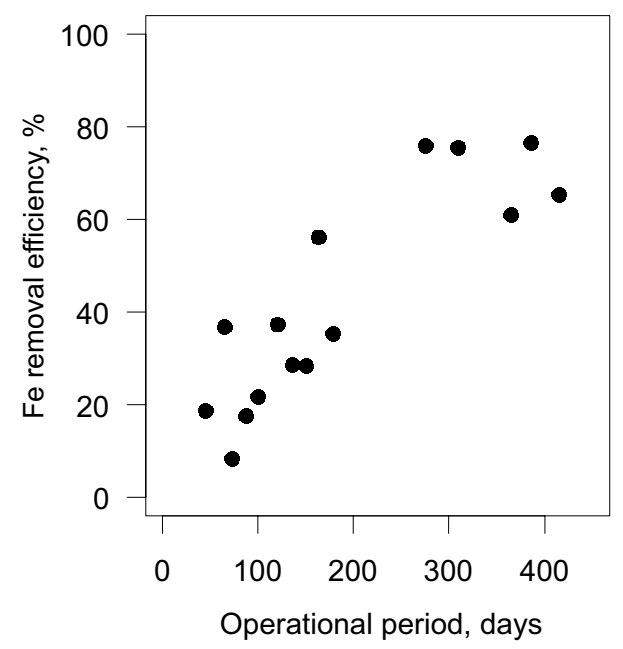

Fig. 3 Fe removal efficiency at the NZ2 trial through time structure may explain the quick formation of a thick layer in such a short time, relative to other trials.

XRD analyses of the sludge layers displayed an amorphous signature in the three VFR trials (NZ2, OH1, and $\mathrm{OH} 2$ ) formed mainly by $\mathrm{Fe}$ and trace concentrations of $\mathrm{S}$ and $\mathrm{Al}$ (Table 5). Different mineral phases could have precipitated according to the SIs calculated after geochemical modelling at the NZ2 trial (Table 4), including a variety of poorly ordered oxides and hydroxysulphates, typical iron precipitates from AMD environments (Bigham et al. 1990; Singh et al. 1999). Greater SIs indicate that schwertmannite was the predominant precipitated phase in the systems (Table 4). Schwertmannite was also likely the main phase in the $\mathrm{OH} 1$ and $\mathrm{OH} 2$ trials since schwertmannite is the most common poorly crystalline $\mathrm{Fe}$ mineral that forms by direct precipitation from $\mathrm{pH} 2.8-4$ water with sulphate concentrations between 1000 and $3000 \mathrm{mg} / \mathrm{L}$ (Bigham et al. 1996). The conditions in the VFR trials also indicate that schwertmannite was likely, since it is typically formed in aerobic environments through bacterially mediated Fe oxidation after exposure to the atmosphere (Fernandez-Martinez et al. 2010).

\section{Acidic Mine Waters $(\mathrm{pH}<3)$}

The performance of the VFR technology under highly acidic conditions ( $\mathrm{pH}$ consistently $<3$ ) was assessed at two mine sites. The MW at the NZ3 site showed lower EC (Table 2) and total acidity values, and $\mathrm{SO}_{4}{ }^{2-}$ and $\mathrm{Al}$ concentrations (Table 3) than the MW from the Bellvue site (NZ4 and NZ5 trials). It also showed slightly lower total Fe inlet concentrations, although all the MWs generally remained in the range 45-70 mg/L (Table 3; Fig. 2a). The main difference between the trials at the Bellvue site was the inlet DO concentrations, which were much higher at the NZ4 trial (Table 2). In all cases, Fe was the main element of concern, with low Fe(II) inlet concentrations, followed by $\mathrm{Al}$ (Table 3; Fig. 2b).

Fe treatment was low under acidic conditions. The best removal efficiencies were achieved at the NZ3 trial during its short operational period, with values less than $22 \%$ and averaging $15.7 \%$. The VFR trial was offline 13 months after the end of the operational period. At the time of decommission it was possible to observe an algae community fully developed in the water column, on top of a thick sludge layer. Although XRD and ICP-OES analyses of the sludge layer confirmed that it consisted on an amorphous iron precipitate with trace concentrations of $\mathrm{S}$ and $\mathrm{Al}$ as the main second and third element concentrations (Table 5), geochemical modeling of the inlet MW indicated that none of the target mineral phases were oversaturated in solution (Table 4). It is possible that the development of the algae community in the water column resulted in changes of $\mathrm{pH}$ and $\mathrm{MW}$ chemistry during the offline period. Thus, the mechanisms 
involved in Fe removal and the formation of the sludge layer remain unclear.

Although low, the Fe removal values obtained at the NZ3 trial are still remarkable, particularly considering the high flows and extremely low HRTs in comparison to the other VFR trials (Table 1). Average MW velocities through the ochre bed varied between 2.9 and $28.8 \mathrm{~m} /$ day with an average of $9.2 \mathrm{~m} /$ day, much higher than the recommended velocities $(<4 \mathrm{~m} /$ day) suggested by Sapsford and Williams (2009). The authors recommend these values due to empirical evidence of lower Fe removal rates achieved in the UK1 trial at velocities greater than $4 \mathrm{~m} /$ day, however it has not been confirmed whether the poorer Fe removal efficiencies above these velocities are due to ochre being scoured from the bed or limited Fe(II) oxidation due to lower HRTs. In any case, the possibility that greater HRTs might result in greater Fe removal under acidic conditions at the NZ3 trial warrants further research and the data again shows that iron removal directly from low $\mathrm{pH}(<3) \mathrm{MW}$ is possible.

Fe removal was less than $15 \%$ in the NZ4 trial, and often $0 \%$ at the NZ5 trial (Fig. 2c). Most of the Fe removed in the NZ4 trial can be related to the filtration of particulate Fe, indicating that no other $\mathrm{Fe}$ removal mechanisms took place at the Bellvue site. This was confirmed by the low saturation indexes using PhreeqC modeling (Table 4), and the absence of any sludge on top of the gravel bed after 13 months of operation.

Two short experiments were carried out to evaluate the effects of mixing freshwater (FW) or FW soaked in limestone clasts (SFW) with the NZ4 MW. Experiments evaluating the mixture with FW onsite at the 2:1 ratio (MW:FW) showed low dissolved Fe removal efficiencies (10.8\%, $\mathrm{pH} 2.84$ ), which increased slightly at the 1:4 mixing ratio (11.5\%, pH 3.38). Mixing with SFW resulted in greater dissolved Fe removal efficiencies at the 2:1 ratio $(36.7 \%, \mathrm{pH}$ 3.17), which reached $99 \%$ at a 1:1 ratio ( $\mathrm{pH} 4.35)$. The added alkalinity consumed protons $\left(\mathrm{H}^{+}\right)$from the $\mathrm{MW}$, increasing $\mathrm{pH}$ and reducing iron solubility. The SFW was more effective due to the greater $\mathrm{HCO}_{3}{ }^{-}$availability after $\mathrm{CaCO}_{3}$ dissolution. The results show that an iron removal efficiency of up to $30 \%$ would be possible in a combined limestone leaching bed and VFR system at low mixing ratios, suggesting that VFR systems could be used as pre-treatment units for acidic coal MW. In such a system, the FW would pass through the limestone leaching bed, and the resulting SFW would be mixed with the MW in the pre-treatment VFR.

\section{Considerations for Application of VFRs for the Passive Treatment of Mine Water}

The information collected from the VFR trials is useful in predicting the iron removal mechanisms expected to occur with this technology across the $\mathrm{pH}$ range (Fig. 4), and allows comparison with other passive treatment technologies. Most iron removal mechanisms are $\mathrm{pH}$-dependent, whereas filtration is always present due to the vertical configuration of the MW through the gravel/ochre bed. As a consequence, the VFR can always function as a filter, which provides the VFR with an additional removal mechanism compared to other horizontal flow passive treatment technologies.

Aerobic wetlands (AWs) are passive treatment systems that typically consist of a shallow $(<30 \mathrm{~cm})$, horizontal surface-flow wetland planted with cattails (Typha sp.). Its use is recommended for net-alkaline mine waters and they are designed to provide sufficient residence time to allow metal oxidation and hydrolysis, thereby causing precipitation and physical retention of $\mathrm{Fe}, \mathrm{Al}$, and $\mathrm{Mn}$ hydroxides (Skousen and Ziemkiewicz 2005). In a VFR, self-filtration of HFO previously formed in the water column and heterogeneous $\mathrm{Fe}$ (II) catalytic oxidation and accretion on HFO are the dominant mechanisms under net-alkaline circumneutral conditions ( $\mathrm{pH} \mathrm{6-8),} \mathrm{with} \mathrm{ferrihydrite} \mathrm{as} \mathrm{the} \mathrm{main} \mathrm{mineral} \mathrm{phase}$ formed (Fig. 4). The greater number of removal mechanisms suggests enhanced iron and manganese removal in VFR systems and therefore a reduced footprint compared to AWs.

Hedin et al. (1994) proposed a sizing criteria for AWs of $10 \mathrm{~g} / \mathrm{m}^{2} /$ day to achieve compliance $(\mathrm{Fe}<3.0 \mathrm{mg} / \mathrm{L})$. However, this proposed criteria should be used with caution, since only one out of the six systems used to calculate this threshold lowered iron concentrations to compliance (Hedin et al. 1994). This is particularly true when the MWs have low influent $\mathrm{Fe}$ concentrations (i.e. $<10 \mathrm{mg} / \mathrm{L}$ ).

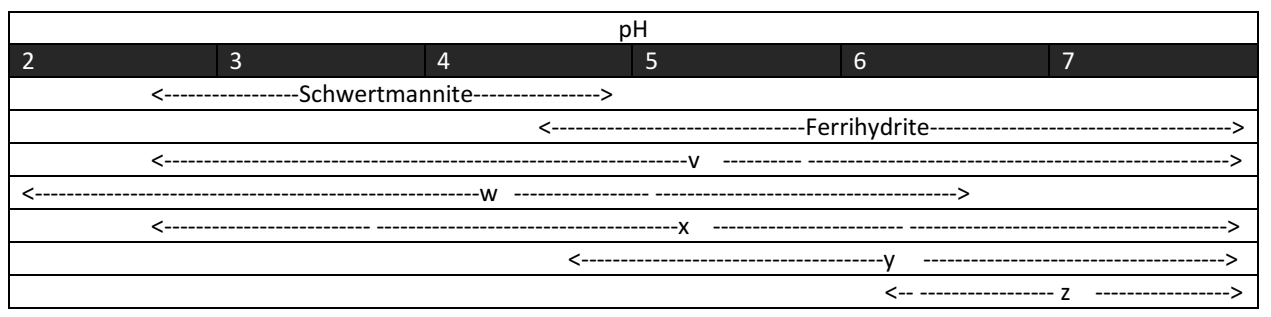

Fig. 4 Iron precipitates and removal mechanisms in VFRs across the $\mathrm{pH}$ range. (1) Filtration of particulate iron. (2) Microbial Fe(II) oxidation. (3) Heterogenous precipitation/aggregation of nanoparticulates.
(4) Heterogeneous Fe(II) oxidation. (5) Heterogeneous and microbial Mn(II) oxidation 
Data collected from monitoring lagoons and wetlands at the UK1 site demonstrated a maximum removal rate of $6.11 \mathrm{~g} / \mathrm{m}^{2} /$ day (Sapsford and Watson 2011). Similarly, the results reported by Banks (2003) from eight AWs provide a useful comparison (Fig. 5a), since in all these cases, iron removal efficiencies frequently exceeded $90 \%$ and effluent iron concentrations were less than $1 \mathrm{mg} / \mathrm{L}$. As shown in Fig. 5a, the UK1 trial iron removal rates (average of $15.3 \mathrm{~g} / \mathrm{m}^{2} /$ day) exceeded significantly the removals found by Sapsford and Watson (2011) and the mean values reported by Banks (2003). The performance of the NZ1 trial, although apparently low (average of $3.57 \mathrm{~g} / \mathrm{m}^{2} /$ day), is relatively high since it was associated with lower inlet flows and Fe concentrations than the UK1 trial. The results from the SK trial suggest that empirical average iron removal rates for AWs and VFRs should be used with caution since they may be highly variable as a result of different flow conditions, water chemistry, and system designs. Based on these results, the footprint of a VFR operating at optimum conditions would be less than half of the area required by a conventional AW system for iron removal, in agreement with previous calculations (Sapsford et al. 2007).

Mn removal rates of the UK1 and SK trials were greater than those reported by Hedin et al. (1994) (Fig. 5b), with averages of 0.97 and $0.72 \mathrm{~g} / \mathrm{m}^{2} / \mathrm{day}$, up to almost double the $0.5 \mathrm{~g} / \mathrm{m}^{2} /$ day sizing criteria recommended for compliance $(\mathrm{Mn}<2.0 \mathrm{mg} / \mathrm{L})$. Again, the performance of the NZ1 trial seems low (average of $0.16 \mathrm{~g} / \mathrm{m}^{2} /$ day) as a result of lower inlet flows and Mn concentrations (Table 3; Fig. 5b). VFRs show more efficient Mn treatment than AWs, which could be due to a combination of biotic and abiotic removal mechanisms enhanced by vertical flow through the ochre sludge layer surface.

The traditional passive technologies designed to treat net-acid MW take advantage of organic substrates to generate reducing conditions and alkaline substrates for acid neutralization (Skousen and Ziemkiewicz 2005). A VFR does not neutralize acidity; however, it provides efficient iron removal under moderately acidic conditions ( $\mathrm{pH} 3-4.5$, Fig. 4), suggesting that it can be used as a pretreatment unit. Its use as a pretreatment system would avoid or diminish the harmful effects of iron precipitation in other treatment units (i.e. limestone armouring). In addition, a VFR has additional advantages such as simple design, materials, and construction, and the production of a dense ochre free of plant detritus amenable to recycling.

It is interesting to provide the empirical $\mathrm{Fe}$ removal rates of the VFR trials treating net-acid MW as a reference for engineers and practitioners (Fig. 5c). The VFR trials provided highly variable $\mathrm{Fe}$ removal rates (averages of 35.4, 11.06 , and $32.9 \mathrm{~g} / \mathrm{m}^{2} /$ day for trials UK2, NZ2, and $\mathrm{OH} 1$ respectively) due to differences in flow, inlet iron concentration, and composition. Similar iron removal rates could be expected from the acidic VFR trials if $\mathrm{pH}$ could be increased upstream using additional treatment units, such as steel slag or limestone leaching beds.

In addition to iron removal, de-sludge frequency is another important parameter for implementation of VFR technology in mine water remediation. The permeability of the ochre sludge layer decreases through time as it builds up, eventually limiting vertical flow through the VFR and causing overflow, as observed in trial $\mathrm{OH} 2$. Periodically, ochre needs to be removed from the VFR system (a)

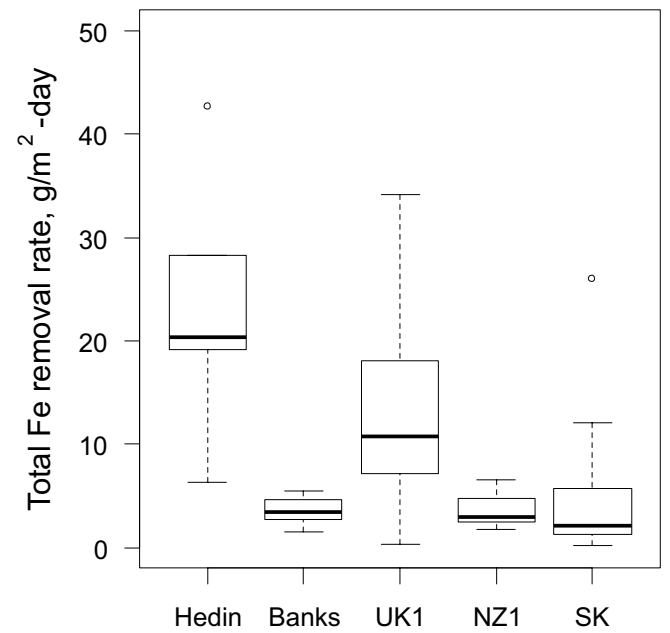

(b)

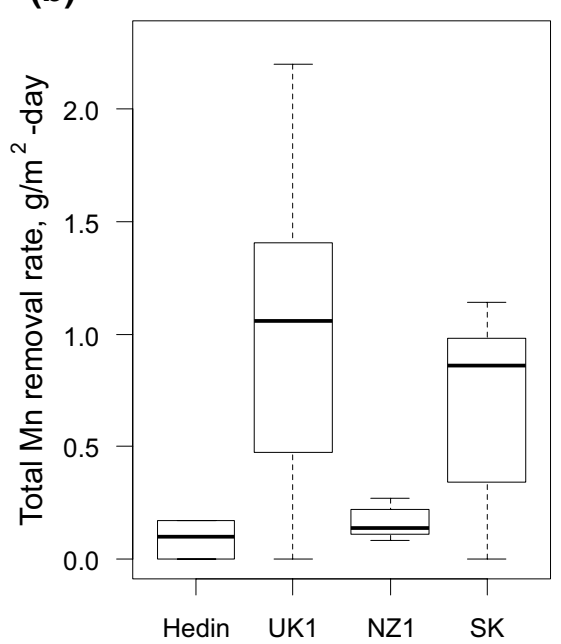

(c) Net-acidic

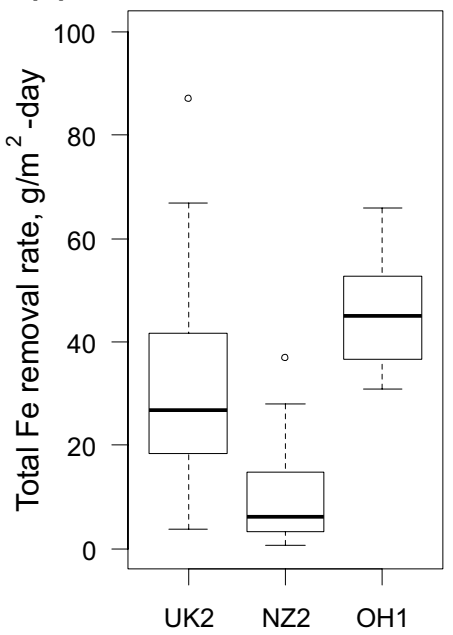

Fig. 5 Boxplot diagrams of total Fe and Mn removal rates under net-alkaline and net-acidic conditions for aerobic wetlands reported by Hedin et al. (1994) (Hedin) and Banks (2003) (Banks), and for the VFR trials 
to re-establish the permeability in the VFR (Sapsford et al. 2007). Differences in thickness through time in the development of the ochre layer were observed among the VFR trials: from slow ( $1 \mathrm{~cm}$ in 14 months, NZ2) to quick formation $(2 \mathrm{~cm}$ in 6 months, OH1). These differences are attributed to inlet flow and water chemistry characteristics, indicating that the development of the ochre layer and the de-sludge frequency are site specific and should be assessed on site.

\section{Conclusions}

This study evaluates new monitoring information from VFR field trials in New Zealand, South Korea, and Ohio (USA) and confirms the removal mechanisms in a VFR across the $\mathrm{pH}$ range in the context of previous research. Filtration of particulate iron is possible across the whole $\mathrm{pH}$ range, in addition to heterogeneous catalytic oxidation of $\mathrm{Fe}$ and precipitation as hydrated ferric oxides and oxyhydroxides (HFO) at circumneutral $\mathrm{pH}(6-8) \mathrm{c}$ and microbial Fe oxidation, heterogeneous $\mathrm{Fe}(\mathrm{III})$ precipitation as schwertmannite, and/or aggregation of colloidal and nano-particulate $\mathrm{Fe}(\mathrm{III})$ precipitates under acidic conditions $(\mathrm{pH}<4.5)$.

The reproducibility of previous research confirms the use of a VFR as a reliable MW passive treatment technology under circumneutral conditions. Its use as a standalone unit would require a footprint less than half of the area required by a conventional aerobic wetland to achieve the same level of iron removal from net-alkaline MWs. The results under moderately acidic conditions were more variable, which is attributed to the range of inlet MW chemistry and length of start-up periods, but the field trials were still able to reproduce the maximum removal rates obtained in previous research. Under these circumstances, the VFR technology may provide useful iron pretreatment for other passive or active treatment technologies. A combination with alkaline generating systems would be required for VFR systems to be used as iron pre-treatment units under strongly acidic conditions.

The VFR technology is ready to move from pilot- to full-scale. The construction of a full-scale demonstration VFR would provide useful information regarding operational parameters including de-sludging techniques and frequency of ochre sludge management and disposal.

Acknowledgements The authors acknowledge the Engineering and Physical Sciences Research Council (EPSRC) for providing funding for this project and the contribution of CRL Energy Ltd., KIGAM, Ohio University, Bathurst Resources Ltd., and O'Kane Consultants Ltd. in carrying out the field research. Paul Webber, William Olds, Eden Sinclair and Hamish McLauchlan acknowledge the CMER project for time to compile data.
Open Access This article is distributed under the terms of the Creative Commons Attribution 4.0 International License (http://creativecommons.org/licenses/by/4.0/), which permits unrestricted use, distribution, and reproduction in any medium, provided you give appropriate credit to the original author(s) and the source, provide a link to the Creative Commons license, and indicate if changes were made.

\section{References}

Banks S (2003) The UK coal authority minewater-treatment scheme programme performance of operational systems. Water Environ J 17:117-122

Barnes A (2008) The rates and mechanisms of Fe(II) oxidation in a passive vertical flow reactor for the treatment of ferruginous mine water. PhD thesis, Cardiff Univ, UK

Bigham J, Schwertmann U, Carlson L, Murad E (1990) A poorly crystallized oxyhydroxysulphate of iron formed by bacterial oxidation of $\mathrm{Fe}(\mathrm{II})$ in acid mine waters. Geochim Cosmochim Acta 54:2743-2758

Bigham J, Schwertmann U, Traina S, Winland R, Wolf M (1996) Schwertmannite and the chemical modeling of iron in acid sulphate waters. Geochim Cosmochim Acta 60:2111-2121

Dey M, Sadler P, Williams K (2003) A novel approach to mine water treatment. Land Contam Reclam 11:253-258

Fernandez-Martinez A, Timon V, Roman-Ross G, Cuello G, Daniels J, Ayora C (2010) The structure of schwertmannite, a nanocrystalline iron oxyhydroxysulphate. Am Mineral 95:1312-1322

Florence K, Sapsford D, Johnson D, Kay C, Wolkersdorfer C (2016) Iron-mineral accretion from acid mine drainage and its application in passive treatment. Environ Technol 37(11):1428-1440

Geroni J (2011) Rates and mechanisms of chemical processes affecting the treatment of ferruginous mine water. PhD thesis, Cardiff Univ, UK

Hedin R, Nairn R, Kleinmann R (1994) Passive Treatment of Coal Mine Drainage. US Bureau of Mines IC 9389, US Dept of the Interior, Washington DC

Kawano M, Tomita K (2001) Geochemical modeling of bacterially induced mineralization of schwertmannite and jarosite in sulfuric acid spring water. Am Miner 86:1156-1165

Kirby C, Brady J (1998) Field determination of $\mathrm{Fe}^{2+}$ oxidation rates in acid mine drainage using a continuously-stirred tank reactor. Appl Geochem 13:509-520

Kirby CS, Cravotta CA III (2005) Net alkalinity and net acidity 2: practical considerations. Appl Geochem 20:1941-1964

Ohio University (2015) 2014 Comprehensive Non-point Source (NPS) monitoring report for acid mine drainage (AMD). Ohio Univ Voinovich School of Leadership and Public Affairs. http:// www.watersheddata.com/UserView_Report.aspx. Accessed 01 Dec 2015

Parkhurst D, Appelo C (2013) Despcription of input and examples for PHREEQC version 3 - a computer program for speciation, batch-reaction, one-dimensional transport, and inverse geochemical calculations: US Geological Survey Techniques and Methods, book 6, chap A43, 497, http://pubs.usgs.gov/tm/06/ a43/

Rice E, Baird R, Eaton A, Clesceri L (2012) Standard methods for the examination of water and wastewater, 22nd edn. American Water Works Assoc, Water Environment Fed, Washington DC, American Public Health Assoc

Rose A (2010) Advances in passive treatment of coal mine drainage 1998-2009. In: Proceedings of the National Meeting of the American Soc of Mining and Reclamation, pp 847-887 
Sapsford DJ, Watson I (2011) A process-orientated design and performance assessment methodology for passive mine water treatment systems. Ecol Eng 37:970-975

Sapsford D, Williams K (2009) Sizing criteria for a low footprint passive mine water treatment system. Water Res 43:423-432

Sapsford D, Barnes A, Dey M, Williams K, Jarvis A, Younger P (2007) Low footprint passive mine water treatment: field demonstration and application. Mine Water Environ 26:243-250

Sapsford D, Santonastaso M, Thorn P, Kershaw S (2015) Conversion of coal mine drainage ochre to water treatment reagent: production, characterisation and application for $\mathrm{P}$ and $\mathrm{Zn}$ removal. $\mathrm{J}$ Environ Manage 1:7-15

Singh B, Fraser A, Wilson M, McHardy W, Merrington G (1999) Mineralogy and chemistry of ochre sediments from an acid mine drainage near a disused mine in Cornwall, UK. Clay Miner 34:301-317

Skousen J, Ziemkiewicz P (2005) Performance of 116 passive treatment systems for acid mine drainage. In: Proceedings of the
National Mtg of the American Soc of Mining and Reclamation, http://anr.ext.wvu.edu/r/download/44882

Skousen J, Sexstone A, Ziemkiewicz P (2000) Acid mine drainage control and treatment. In: Barnhisel RI, Darmody RG, Lee DW (eds) Reclamation of drastically disturbed lands, Agronomy Monograph 41. American Soc of Agronomy, Crop Science Soc of America, Soil Science Soc of America, Madison, WI, pp 131-168

Trumm D (2010) Selection of active and passive treatment systems for AMD - flow charts for New Zealand conditions. New Zeal J Geol Geophys 53:195-210

Wieder R, Lang G (1982) Modification of acid mine drainage in a freshwater wetland. Paper at Symp on Wetlands of the Unglaciated Appalachian Region, https://wvmdtaskforce.files.wordpress. com/2015/12/82-lang.pdf

Yim G, Cheong Y, Hong J, Hur W (2014) The role of each compartment in a two-compartment vertical flow reactor for ferruginous mine water treatment. Water Res 62:11-19 